\title{
The Expression of Angiogenic Protein Cyr61 Significantly Increases in the Urine of Early-Onset Preeclampsia Patients
}

\section{Anjiyojenik Protein Cyr61'in Ekspresyonu, Erken Başlangıçlı Preeklampsi Hastalarının İdrarında Önemli Ölçüde Artar}

\author{
Mustafa Behram', @Süleyman Cemil Oğlak² \\ ${ }^{1}$ Health Sciences University, Kanuni Sultan Süleyman Training and Research Hospital, Department of Perinatology, Istanbul, Turkey \\ 2 Health Sciences University, Gazi Yaşargil Training and Research Hospital, Department of Obstetrics and Gynecology, Diyarbakır, Turkey
}

\begin{abstract}
Aim: This study sought to compare the expression of the Cysteinerich 61 (Cyr61) protein in the urine of early-onset preeclampsia (PE) patients with that of the urine of normotensive healthy pregnant women.

Material and Method: A total of 80 patients who gave birth from June 2019 to December 2019 were enrolled in this prospective study. The study group comprised 40 pregnant women at 20-34 weeks of gestation who presented with early-onset PE. Gestational age- and body mass index-matched, 40 healthy normotensive pregnant women without proteinuria were included in the control group. We recorded demographic characteristics and urine Cyr61 concentrations of the participants.
\end{abstract}

Results: The urine Cyr61 protein levels were significantly higher in the early-onset PE group $(922.6 \pm 1263.1 \mathrm{pg} / \mathrm{mL})$ than those of the control group (499.2 $\pm 270.2 \mathrm{pg} / \mathrm{mL}, \mathrm{p}<0.001)$. As a result of the ROC analysis, the area under the curve $(\mathrm{aHR}=0.690,95 \% \mathrm{Cl}=0.556-0.813)$ was found to be significant ( $p=0.003$ ). So, it was seen that Cyr61 could be used for the diagnosis of early-onset PE. The values 981.52 $\mathrm{pg} / \mathrm{mL}$ and above, corresponding to $67.5 \%$ of sensitivity and $72.5 \%$ of specificity points, can be used as a cut-off which is calculated by the Youden index, can be used to diagnose early-onset PE.

Conclusion: This study found an increased Cyr61 protein level in the urine of the early-onset PE patients compared with the urine of healthy pregnancies. The increased presence of Cyr61 protein in the urine could serve as a predictive tool for the early diagnosis of early-onset PE and renal ischemia.

Keywords: Cysteine-rich protein 61, early-onset preeclampsia,renal ischemia.
Öz

Amaç: Bu çalışma, erken başlangıçlı preeklampsi (PE) hastalarının idrarındaki Sistein açısından zengin 61 proteinin (Cyr61) ekspresyonunu normotansif sağlıklı hamile kadınların idrarıyla karşılaştırmayı amaçladı.

Gereç ve Yöntem: Bu prospektif çalışmaya Haziran 2019 ile Aralık 2019 tarihleri arasında doğum yapan toplam 80 hasta dahil edildi. Çalışma grubu, erken başlangıçlı PE ile başvuran 20-34. gebelik haftalarındaki 40 gebe kadından oluşturuldu. Kontrol grubuna, gebelik yaşı ve vücut kitle indeksi uyumlu, proteinürisi olmayan 40 sağlıklı normotansif gebe alındı. Katılımcıların demografik özelliklerini ve idrar Cyr61 konsantrasyonlarını kaydettik.

Bulgular: İrar Cyr61 protein seviyeleri erken başlangıçlı PE grubunda $(922,6 \pm 1263,1 \mathrm{pg} / \mathrm{mL})$ kontrol grubuna $(499,2 \pm 270,2 \mathrm{pg} / \mathrm{mL}$, p<0,001) göre anlamlı ölçüde daha yüksekti. ROC analizi sonucunda, eğri altındaki alan (aHR=0,690, \%95 $\mathrm{Cl}=0,556-0,813)$ anlamlı bulundu ( $p=0,003)$. Böylece, Cyr61'in erken başlangıçlı PE tanısında kullanılabileceği görüldü. Youden indeksi ile hesaplanan, \%67,5 sensitivite ve \%72,5 özgüllük noktalarına karşılık gelen 981,52pg/mL eşik değeri erken başlangıçlı PE'yi teşhis etmek için kullanılabilir.

Sonuç: Bu çalışmada, erken başlangıçlı PE hastalarının idrarında sağlıklı gebelerin idrarına kıyasla daha yüksek Cyr61 protein düzeyi bulunmuştur. İdrarda artan Cyr61 protein düzeyi, erken başlangıçı PE ve renal iskeminin erken teşhisi için öngörücü bir belirteç olarak kullanılabilir.

Anahtar Kelimeler: Sistein açısından zengin protein 61, erken başlangıçlı preeklampsi, renal iskemi

Corresponding (illetişim): Süleyman Cemil Oğlak. Department of Obstetrics and Gynecology, Health Sciences University, Gazi Yaşargil Training and Research Hospital, Diyarbakır Turkey

E-mail (E-posta): sampson_21@hotmail.com

Received (Geliş Tarihi): 31.05.2021 Accepted (Kabul Tarihi): 25.06.2021 


\section{INTRODUCTION}

Preeclampsia (PE) is defined as a new onset of hypertension following 20 weeks of pregnancy in a previously normotensive gravid co-occurring either proteinuria or end-organ dysfunction. ${ }^{[1,2]}$ This pregnancy complication constitutes one of the major causes of maternal and fetal morbidity and mortality, affecting $2-8 \%$ of all pregnancies worldwide. $^{[3]}$ PE is associated with adverse pregnacy outcomes, including maternal end-organ damage, growth restriction, oligohydramnios, preterm birth, and fetal and neonatal mortality. ${ }^{[4,5]}$

In a healthy pregnancy, highly invasive extravillous trophoblast (EVT) cells migrate through the uterine wall, erode the spiral arteries, remodel these arteries by replacing the vascular endothelial and muscle cells, and transforming them into the low resistant vessels to provide high blood flow capacity. ${ }^{[6,7]}$ If any EVT cells' migration and invasion characteristics are defected or disturbed, it could result in a shallow invasion of EVT cells into the decidua and vessels, accompanied by inadequate remodeling of the maternal vascular structures seen in the preeclamptic placenta. [8-12] This incomplete remodeling induces uteroplacental insufficiency and fetal growth restriction, which could affect placental development and angiogenesis. ${ }^{[13]}$

Cysteine-rich 61 (Cyr61, CCN1), a component of the CCN protein family, is a secreted matricellular protein expressed by stromal cells, vessel's endothelial cells, and interstitial EVT giant cells, and implicated in diverse cellular processes, including angiogenesis, adhesion migration, formation, proliferation, and apoptosis. ${ }^{[14]}$ Also, Cyr61 is highly expressed in the human placenta during embryogenesis. ${ }^{[14,15]}$ However, the immunohistochemical examination of preeclamptic placental tissues and the analysis of serum samples of preeclamptic patients showed reduced expression of Cyr61. $[16,17]$

During a healthy pregnancy, the kidney experiences significant physiologic and anatomic adaptive alterations performing a pivotal role in gestation. These changes make the kidney vulnerable to conclusions happening in PE. ${ }^{[18]}$ The kidney is one of the organs targeted by PE, causing abnormal renal histology, proteinuria, renal ischemia, and renal dysfunction. ${ }^{[19,20]}$ Cyr61 is considered to aid in numerous events, including neovascularization, wound healing, and organ development. ${ }^{[21]}$ Prior researches have identified the low secretion level of Cyr61 in a healthy kidney and high secretion of Cyr61 in the ischemic kidney, which recommends that Cyr61 might be a potential marker for diagnosis of renal ischemia. ${ }^{[22]}$ Therefore, we assumed that we might detect Cyr61 in the urine following renal ischemia caused by PE.

This study sought to compare the expression of the Cyr61 protein in the urine of early-onset PE patients with that of the urine of normotensive healthy pregnant women.

\section{MATERIAL AND METHOD}

This prospective study was conducted at the XX Hospital. A total of 80 patients who gave birth from June 2019 to December 2019 were enrolled in the study. The study group comprised 40 pregnant women aged between 18-35 years at 24-34 weeks of gestation who presented with early-onset PE. Gestational age- and body mass index (BMI)-matched 40 healthy pregnant normotensive patients without proteinuria were included in the control group. The control group consisted of pregnant women who did not experience any adverse outcomes associated with pregnancy in the later weeks of pregnancy and had given birth at term.

We used the ACOG criteria for PE definition. ${ }^{[23]}$ Early-onset PE were defined after 20th week of pregnancy as hypertension (systolic blood pressure [BP] of $\geq 140 \mathrm{~mm} \mathrm{Hg}$, or diastolic BP of $\geq 90 \mathrm{~mm} \mathrm{Hg}$ on two times at least 4 hours apart [unless antihypertensive therapy is started at this point]), and the presence of proteinuria ( $\geq 300 \mathrm{mg} / 24 \mathrm{~h}$ urine collection [or this amount extrapolated from a timed collection], or protein/ creatinine ratio of $\geq 0.3 \mathrm{mg} / \mathrm{dL}$, or dipstick examination of $2+$ [practiced only if other quantitative techniques not accessible]). In the absence of proteinuria, if the pregnant women suffered from gestational hypertension present with any of the following characteristics, they were diagnosed as preeclampsia: impaired liver function as shown by abnormally elevated blood concentrations of liver enzymes (to twice the higher limit standard concentration), thrombocytopenia (platelet count $<100,000 \times 10^{9} / \mathrm{L}$ ), and severe persistent right upper quadrant or epigastric pain unresponsive to medication, renal insufficiency (serum creatinine concentration $>1.1 \mathrm{mg} /$ $\mathrm{dL}$ or a doubling of the serum creatinine concentration in the lack of other renal disorder), visual disturbances, new-onset headache unresponsive to medication and not considered for by alternative diagnoses, and pulmonary edema.

We excluded patients with multiple pregnancies, eclampsia, HELLP syndrome, ruptured amniotic membranes, anemia, infections, fever, and co-existing morbidities, including diabetes mellitus, thyroid disorders, chronic hypertension, renal disease, hepatic disease, collagen vascular disease, and known malignancy. Patients at the active phase of labor, a previous history of gestational hypertensive disorders, patients with incomplete or unavailable medical records were also excluded.

We collected blood and urine samples of the patients at the PE diagnosis period before any treatment for the study group, and during routine antenatal care before labor for the control group. At the time of the maternal urine sample collection, the gestational age and BMI of the patients were matched, and the two groups were similar in terms of gestational age and BMI. We recorded maternal age, parity, BMI, gestational age at urine sample collection, systolic and diastolic BP, amount of proteinuria, white blood cell (WBC) count, hemoglobin value, platelet count, blood urea nitrogen (BUN), creatinine, AST, ALT, birth week, birth weight, and urine Cyr61 levels of the patients. 
The urine concentration of Cyr61 was measured in duplicate using an enzyme-linked immunoassay (ELISA) kit (Catalog Number: SEG313Hu; Cloud-Clone Corp. 23603 W. Fernhurst Dr., Unit 2201, Katy, TX 77494, USA) according to the manufacturer's protocol. The intra- and interassay coefficients of variations were $<10 \%$ and $<12 \%$ respectively.

The ethics committee of the Kanuni sultan Süleyman Training and Research Hospital approved the study (2019.04.83). An informed consent form was obtained from all patients. .

\section{Statistical Analysis}

We used IBM SPSS 21.0 for Windows (SPSS Inc., Chicago, IL, USA) statistical package program for statistical evaluation of our research data. We presented measured variables as mean \pm standard deviation (std), and categorical variables as numbers and percentages (\%). The Kolmogorov-Smirnov test was used to determine whether the numerical data matched the normality distribution. The Chi-square and Fisher exact tests were used for pairwise comparisons. We used the Mann-Whitney $\mathrm{U}$ test to compare the non-normally distributed data. Differences were considered statistically significant at $P$-value $<0.05$. We used a receiver operating characteristic (ROC) curve to evaluate the sensitivity and specificity performance characteristics of Cyr61, and estimated a cut-off value by using the index of Youden.

Group sample sizes of 40 and 40 achieve $80 \%$ power to detect a difference of $35 \%$ between the control and early-onset PE groups with estimated group standard deviations of 270.2 and 280.0 and with a significance level (alpha) of 0.05 using a two-sided two-sample t-test.

\section{RESULTS}

Throughout the study period from June 2019 to December 2019, 63 patients suffered from early-onset PE were admitted to our hospital. Four patients had a history PE in their previous pregnancies. Four patients were at the active phase of labor. Three patients had chronic hypertension. Two patients did not wish to participate and withdrew from the study. We also excluded ten patients per the other exclusion criteria. A total of 40 pregnant patient suffered from early-onset PE entirely fulfilled the inclusion criteria for the final analysis (Figure 1).

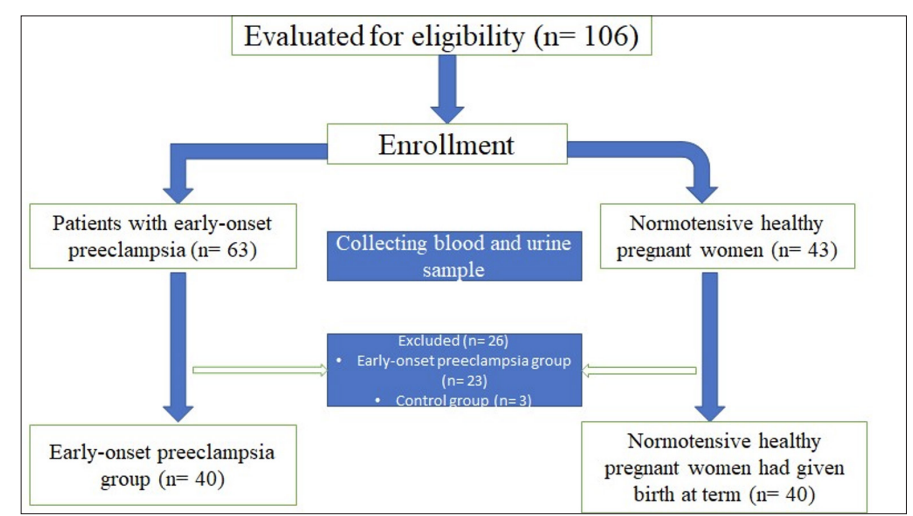

Figure 1. Flow diagram of the study
We summarized the demographic and clinical characteristics of the participants in Table 1. There were no significant differences between the two groups in terms of maternal age, number of nulliparous patients, BMl, and gestational age at urine sample collection.

The urine Cyr61 protein levels were significantly higher in the early-onset PE group $(922.6 \pm 1263.1 \mathrm{pg} / \mathrm{mL})$ than those of the control group (499.2 $\pm 270.2 \mathrm{pg} / \mathrm{mL}, \mathrm{p}<0.001$, Table 1).

\begin{tabular}{|c|c|c|c|}
\hline & $\begin{array}{c}\text { Early-onset } \\
\text { preeclampsia } \\
\text { group }(n=40)\end{array}$ & $\begin{array}{c}\text { Control } \\
\text { group }(n=40)\end{array}$ & $P$ value \\
\hline Maternal age, years & $25.2 \pm 3.1$ & $26.3 \pm 2.9$ & 0.618 \\
\hline Nulliparous, n (\%) & $26(65 \%)$ & $21(52.5 \%)$ & 0.223 \\
\hline Body Mass Index, $\mathrm{kg} / \mathrm{m}^{2}$ & $24.7 \pm 2.2$ & $23.6 \pm 2.7$ & 0.464 \\
\hline Systolic Blood Pressure, $\mathrm{mmHg}$ & $146.8 \pm 6.2$ & $114.2 \pm 6.7$ & $<0.001$ \\
\hline Diastolic Blood Pressure, $\mathrm{mmHg}$ & $97.1 \pm 3.4$ & $73.2 \pm 3.9$ & $<0.001$ \\
\hline $\begin{array}{l}\text { Gestational age at urine sample } \\
\text { collection, weeks }\end{array}$ & $30.2 \pm 4.2$ & $30.5 \pm 3.9$ & 0.813 \\
\hline $\mathrm{WBC}, / \mathrm{mm}^{3} \times 10^{3}$ & $12.26 \pm 3.16$ & $11.82 \pm 2.83$ & 0.336 \\
\hline Hemoglobin, g/dL & $11.94 \pm 1.27$ & $11.32 \pm 1.51$ & 0.728 \\
\hline Platelet, $/ \mathrm{mm}^{3} \times 10^{3}$ & $241.17 \pm 72.19$ & $271.27 \pm 56.43$ & $<0.001$ \\
\hline BUN, mg/dL & $13.78 \pm 4.63$ & $10.16 \pm 3.22$ & 0.165 \\
\hline Creatinine, $\mathrm{mg} / \mathrm{dL}$ & $0.89 \pm 0.47$ & $0.51 \pm 0.26$ & 0.094 \\
\hline AST, U/L & $40.66 \pm 78.77$ & $23.17 \pm 9.25$ & $<0.001$ \\
\hline $\mathrm{ALT}, \mathrm{U} / \mathrm{L}$ & $35.57 \pm 67.90$ & $19.43 \pm 7.71$ & $<0.001$ \\
\hline Proteinuria, mg/24-hour & $4929.37 \pm 6682.38$ & N/A & N/A \\
\hline Birth week & $30.6 \pm 3.9$ & $38.4 \pm 1.2$ & $<0.001$ \\
\hline Birth weight & $1558.9 \pm 686.9$ & $3352 \pm 346.1$ & 0.006 \\
\hline Urine Cyr61, pg/mL & $922.6 \pm 1263.1$ & $499.2 \pm 270.2$ & $<0.001$ \\
\hline
\end{tabular}

As a result of the ROC analysis, the area under the curve (aHR $=0.690,95 \% \mathrm{Cl}=0.556-0.813$ ) was found to be significant $(p=0.003)$. So, it was seen that Cyr61 could be used for the diagnosis of early-onset PE. The values $981.52 \mathrm{pg} / \mathrm{mL}$ and above, corresponding to 67.5 sensitivity and 72.5 specificity points, can be used as a cut-off which is calculated by the Youden index, can be used to diagnose early-onset PE (Table 2, Figure 2).

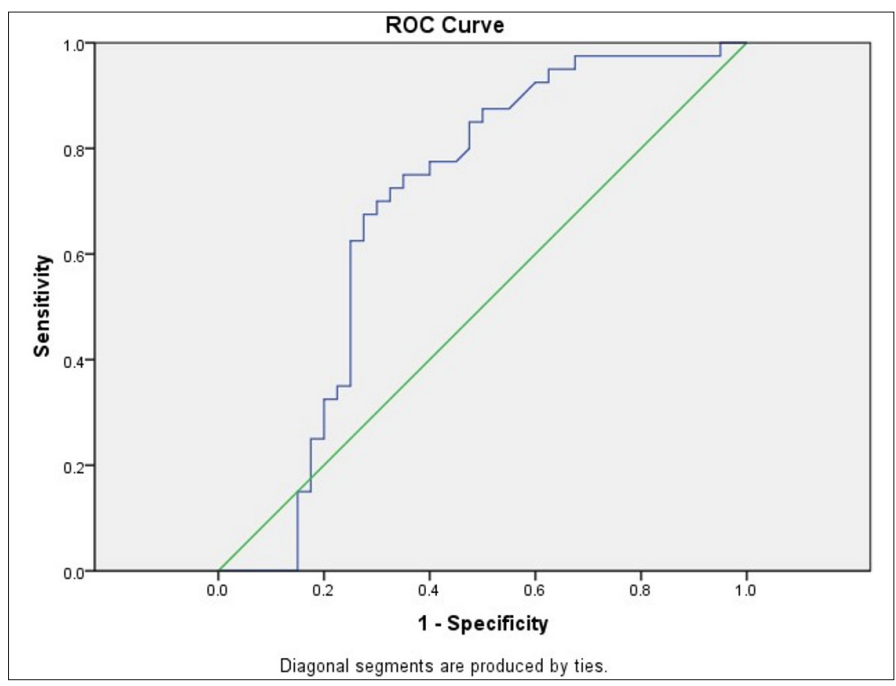

Figure 2. ROC curve for Cyr61 value for predicting early-onset preeclampsia 
Table 2. The area under the curve of Cyr61 value

\begin{tabular}{cccccc} 
& \multirow{2}{*}{ ROC } & \multirow{2}{*}{ St.Error } & \multicolumn{2}{c}{$\mathbf{9 5 \% \text { Confidence Interval }}$} & \multirow{2}{*}{$\mathbf{p}$} \\
\cline { 4 - 5 } & & & Lower & Upper & \\
\hline Cyr61 & 0.690 & 0.063 & 0.566 & 0.813 & 0.003 \\
\hline
\end{tabular}

\section{DISCUSSION}

Our study indicates that the Cyr61 protein demonstrated significantly increased secretion levels in the urine of patients suffering from early-onset PE compared with normotensive gestational age- and BMI-matched controls. The excess of molecules involved in the PE pathogenesis suggests that a single mechanism may not describe the development of this disease, and it could stem from several reasons. ${ }^{[16]}$ Therefore, it isn't easy to discover a proper marker among these molecules for PE, and until presently, a useful marker has not yet been developed. Since the Cyr61 urine protein level was discovered to be noticeably increased in early-onset PE patients, we could serve this protein as a new biomarker for this disease.

Previous data proposes that PE and other gestational hypertensive diseases are a significant contributor to the burden of renal ischemia. ${ }^{[24]} A$ recent study reported that $P E$, especially severe $P E$, is the most common cause of renal ischemia during pregnancy. ${ }^{[25]}$ Researchers formerly considered that the organ dysfunction that occurs with PE reversed after delivery. However, current studies reported that $P E$ is related to an increased risk of chronic or future renal disease. ${ }^{[26]}$ The histopathological examination of PE patients' kidneys during the antepartum or postpartum period showed protein casts in the tubules, proliferation of mesangial cells, vacuolation of podocytes, and endotheliosis. ${ }^{[27]}$

The imbalance in the production of growth and angiogenic factors at the placenta and their secretion into the maternal blood may drive to the clinical sign of $\mathrm{PE}$, including proteinuria and hypertension. ${ }^{[15]}$ Vascular endothelial growth factor (VEGF) seems to perform a pivotal role in the connection between endotheliosis and proteinuria development. ${ }^{[28]}$ The podocyte-derived VEGF binds to endothelial cells, inducing the maturity and the structural integrity of the glomerular endothelium, and maintaining glomerular filter integrity by binding on podocytes. ${ }^{[18]}$ In PE, the reducing levels of VEGF damage the ECs and the glomeruli. These ECs begin to produce endothelin-1 (ET1), which has a potential connection between endothelial dysfunction and altered podocyte integrity and function. ET1's release causes following podocyte-associated protein shedding from podocytes. ${ }^{[29]}$ The shedding of the podocytes is related to the severity of $\mathrm{PE}$, and the urine levels of podocyte-associated proteins are correlated with the amount of proteinuria. ${ }^{[30]}$

Cyr61 can be observed in healthy embryonic glomeruli and human podocytes. Cyr61 is a secreted protein that acts as a matricellular signaling factor competent for many functions, including migration, proliferation, adhesion of fibroblasts and ECs, and wound healing, and increases in the inflammatory response and other injury circumstances. ${ }^{[31]} \mathrm{Li}$ et al. ${ }^{[22]}$ reported that Cyr61 protein significantly increased at $3 \mathrm{~h}$ following renal ischemia, reached the basal level at $24 \mathrm{~h}$, and could be detected early after ischemia in the rat urine. They stated that urine Cyr61 protein is an outstanding biomarker of renal ischemia, and better than the serum creatinine ( $\mathrm{Scr}$ ) for early diagnosis of renal ischemia. Because of the physiological alterations and increase in glomerular filtration rate (GFR), a decrease of Scr occurs during pregnancy, causing the correct and immediate diagnosis of renal ischemia more difficult and masks the renal function changes. It is not always possible to compare the renal function parameters with the patient's baseline values. Furthermore, pregnant women may have a $30-40 \%$ reduction in GFR without significant increases in Scr. ${ }^{[25,32]}$ In our study, urine Cyr61 expression levels in the placentas of PE $(922.6 \pm 1263.1 \mathrm{pg} / \mathrm{mL})$ were higher than those in healthy pregnancy $(499.2 \pm 270.2 \mathrm{pg} / \mathrm{mL}, \mathrm{p}<0.001)$. This result suggests that Cyr61 may be a new marker for the diagnosis of earlyonset PE and also could be used to diagnose renal ischemia early.

Lai et al. ${ }^{[33]}$ stated that the inhibition of Cyr61 reduces renal inflammation and fibrosis after renal ischemia. Liu et al. ${ }^{[34]}$ pointed out that Cyr61 was related to fibrosis in the longterm of ischemia, that the Cyr61 expression was positively associated with renal fibrosis after renal ischemia. These consequences confirm that PE increases the risk of chronic or future renal disease and may cause permanent kidney damage without preexisting renal disease. However, it is not evident whether Cyr61 can be utilized as a potential marker of the progression of acute to chronic renal disease. ${ }^{[22]}$

The main limitation of this study is that we did not compare the urine Cyr61 values with patients'GFR. The main strength of this study is that, to the best of our knowledge, this study, for the first time, provides evidence that Cyr61 protein upregulates in the urine of PE patients. Further studies of Cyr61 signaling pathways are required to clarify its mechanisms of action in PE and future renal disease.

\section{CONCLUSION}

In this study, we found an increased Cyr61 protein level in the urine of the early-onset PE patients compared with the urine of gestational age-matched healthy pregnancies. The increased presence of Cyr61 protein in the urine could serve as a predictive tool for the early diagnosis of early-onset PE and renal ischemia.

\section{ETHICAL DECLARATIONS}

Ethics Committee Approval: The ethics committee of the Kanuni sultan Süleyman Training and Research Hospital approved the study (2019.04.83). An informed consent form was obtained from all patients.

Informed Consent: All patients signed the free and informed consent form.

Referee Evaluation Process: Externally peer-reviewed. 
Conflict of Interest Statement: The author(s) declared no potential conflicts of interest with respect to the research, authorship, and/or publication of this article.

Financial Disclosure: The authors declared that this study has received no financial support.

Author Contributions: All of the authors declare that they have all participated in the design, execution, and analysis of the paper, and that they have approved the final version.

\section{REFERENCES}

1. Behram M, Oğlak SC, Doğan Y. Evaluation of BRD4 levels in patients with early-onset preeclampsia. J Gynecol Obstet Hum Reprod 2021;50(2):101963.

2. Oğlak SC, Tunç Ş, Obut M, Şeker E, Behram M, Tahaoğlu AE. Maternal nearmiss patients and maternal mortality cases in a Turkish tertiary referral hospital. Ginekol Pol 2021;92(4):300-5.

3. Mannaerts D, Heyvaert S, De Cordt C, Macken C, Loos C, Jacquemyn Y. Are neutrophil/lymphocyte ratio (NLR), platelet/lymphocyte ratio (PLR), and/ or mean platelet volume (MPV) clinically useful as predictive parameters for preeclampsia?. J Matern Fetal Neonatal Med 2019;32(9):1412-9.

4. Oğlak SC, Bademkıran MH, Obut M. Predictor variables in the success of slow-release dinoprostone used for cervical ripening in intrauterine growth restriction pregnancies. J Gynecol Obstet Hum Reprod 2020;49(6):101739.

5. Mol BWJ, Roberts CT, Thangaratinam S, Magee LA, de Groot CJM, Hofmeyr GJ. Pre-eclampsia. Lancet 2016;387(10022):999-1011.

6. Behram M, Oğlak SC, Dağ I. Circulating levels of Elabela in pregnant women complicated with intrauterine growth restriction. J Gynecol Obstet Hum Reprod 2021;50(8):102-27.

7. Fisher $\mathrm{SJ}$. Why is placentation abnormal in preeclampsia?. Am J Obstet Gynecol 2015;213(4 Suppl):115-22.

8. Knöfler M, Haider S, Saleh L, Pollheimer J, Gamage TKJB, James J. Human placenta and trophoblast development: key molecular mechanisms and model systems. Cell Mol Life Sci 2019;76(18):3479-96.

9. Kwak YT, Muralimanoharan S, Gogate AA, Mendelson CR. Human Trophoblast Differentiation Is Associated With Profound Gene Regulatory and Epigenetic Changes. Endocrinology 2019;160(9):2189-203.

10. Oğlak SC, Aydın MF. Are neutrophil to lymphocyte ratio and platelet to lymphocyte ratio clinically useful for the prediction of early pregnancy loss? Ginekol Pol 2020;91(9):524-7.

11.Zhang Y, Cao L, Jia J, et al. CircHIPK3 is decreased in preeclampsia and affects migration, invasion, proliferation, and tube formation of human trophoblast cells. Placenta 2019;85:1-8.

12. Obut M, Oğlak SC. Expression of CD44 and IL-10 in normotensive and preeclamptic placental tissue. Ginekol Pol 2020;91(6):334-41.

13. Wolf $N$, Yang $W$, Dunk $C E$, et al. Regulation of the matricellular proteins CYR61 (CCN1) and NOV (CCN3) by hypoxia-inducible factor1 alpha\} and transforming-growth factor-\{beta\}3 in the human trophoblast. Endocrinology 2010;151(6):2835-45.

14. Zhang Y, Diao Z, Su L, et al. MicroRNA-155 contributes to preeclampsia by down-regulating CYR61. Am J Obstet Gynecol 2010;202(5):466.e1-466. e4667.

15. Gellhaus A, Schmidt M, Dunk C, Lye SJ, Kimmig R, Winterhager E. Decreased expression of the angiogenic regulators CYR61 (CCN1) and NOV (CCN3) in human placenta is associated with pre-eclampsia. Mol Hum Reprod 2006;12(6):389-99.

16. Gellhaus A, Schmidt M, Dunk C, Lye SJ, Winterhager E. The circulating proangiogenic factors CYR61 (CCN1) and NOV (CCN3) are significantly decreased in placentae and sera of preeclamptic patients. Reprod Sci 2007;14(8 Suppl):46-52.

17. Chen X, Liu Y, Xu X, Chen H. Decreased Cyr61 under hypoxia induces extravillous trophoblasts apoptosis and preeclampsia. J Huazhong Univ Sci Technolog Med Sci 2011;31(2):235-40.
18. Di Leo V, Capaccio F, Gesualdo L. Preeclampsia and Glomerulonephritis: A Bidirectional Association. Curr Hypertens Rep 2020;22(5):36.

19. Choi SY, Kim KH, Lee M, Yeo MK, Kim J, Suh KS. Complement Component C4d Deposition in the Placenta of Preeclampsia Patients and Renal Glomeruli in 1 Postpartum Renal Biopsy. Appl Immunohistochem Mol Morphol 2020;28(2):139-45.

20. Moghaddas Sani H, Zununi Vahed S, Ardalan M. Preeclampsia: A close look at renal dysfunction. Biomed Pharmacother 2019;109:408-16.

21. Zhang X, Ding L, Diao Z, Yan G, Sun H, Hu Y. CYR61 modulates the vascular endothelial growth factor $\mathrm{C}$ expression of decidual NK cells via PI3K/AKT pathway. Am J Reprod Immunol 2012;67(3):216-23.

22. Li C, Zhao L, Wang Y, et al. Cysteine-rich protein 61, a specific ultra-early biomarker in kidney ischemia/reperfusion injury. Nephrology (Carlton) 2019;24(8):798-805.

23. ACOG Practice Bulletin No 202: Gestational Hypertension and Preeclampsia. Obstet Gynecol 2019;133(1):e1-e25.

24. Phipps EA, Thadhani $R$, Benzing $T$, Karumanchi SA. Pre-eclampsia: pathogenesis, novel diagnostics and therapies. Nat Rev Nephrol 2019;15(5):275-89.

25. Szczepanski J, Griffin A, Novotny S, Wallace K. Acute Kidney Injury in Pregnancies Complicated With Preeclampsia or HELLP Syndrome. Front Med (Lausanne) 2020;7:22.

26. Wiles K, Chappell L, Clark K, et al. Clinical practice guideline on pregnancy and renal disease. BMC Nephrol 2019;20(1):401.

27. Han L, Yang Z, Li K, et al. Antepartum or immediate postpartum renal biopsies in preeclampsia/eclampsia of pregnancy: new morphologic and clinical findings. Int J Clin Exp Pathol 2014;7(8):5129-43.

28. Moghaddas Sani H, Zununi Vahed S, Ardalan M. Preeclampsia: A close look at renal dysfunction. Biomed Pharmacother 2019;109:408-16.

29. Wang Y, Zhao S, Gu Y, Lewis DF. Loss of slit protein nephrin is associated with reduced antioxidant superoxide dismutase expression in podocytes shed from women with preeclampsia. Physiol Rep 2018;6(13):e13785.

30. Wang Y, GuY, Loyd S, Jia X, Groome LJ. Increased urinary levels of podocyte glycoproteins, matrix metallopeptidases, inflammatory cytokines, and kidney injury biomarkers in women with preeclampsia. Am J Physiol Renal Physiol 2015;309(12):1009-17.

31. Muramatsu $Y$, Tsujie M, Kohda $Y$, et al. Early detection of cysteine rich protein 61 (CYR61, CCN1) in urine following renal ischemic reperfusion injury. Kidney Int 2002;62(5):1601-10.

32. Fakhouri F, Vercel C, Frémeaux-Bacchi V. Obstetric nephrology: AKI and thrombotic microangiopathies in pregnancy. Clin J Am Soc Nephrol 2012;7(12):2100-6

33. Lai CF, Lin SL, Chiang WC, et al. Blockade of cysteine-rich protein 61 attenuates renal inflammation and fibrosis after ischemic kidney injury. Am J Physiol Renal Physiol 2014;307(5):581-92.

34. Liu H, Zhang J, Liu X, Li C, Ma R, Xu Y. Effect and mechanism of cysteine-rich protein 61 on transforming growth factor- $\beta 1$-activated renal fibroblasts. Chinese Journal of Nephrology 2017;9:704-10. 